\title{
PENGARUH UKURAN KINERJA ROA, ROE, EPS DAN EVA TERHADAP RETURN SAHAM
}

\author{
Iwin Arnova \\ Program studi Akuntansi \\ Universitas Prof DR Hazairin SH Bengkulu \\ Iwinarnova89@ymail.com
}

\begin{abstract}
ABSTRAK
Iwin Arnova; Penelitian ini bertujuan untuk mengetahui pengaruh Return on Asset, Return on Equity, Laba Per Saham, dan Economic Value Added terhadap return saham. Penelitian ini masih dilakukan menganggap hasil yang berbeda dari berbagai penelitian. Penelitian ini dilakukan dengan menggunakan data sekunder. Populasi dalam penelitian ini adalah seluruh perusahaan manufaktur yang terdaftar di Bursa Efek Indonesia (BEI) dari tahun 2008-2011. Metode pengambilan sampel menggunakan teknik purposive sampling. Pada 48 sampel. Data analisis menggunakan analisis regresi berganda. Hasil analisis regresi menunjukkan bahwa pengembalian aset memiliki efek positif dan signifikan terhadap return saham. Return on Equity dan Laba Per Saham tidak berpengaruh terhadap return saham, sedangkan Economic Value Added berpengaruh negatif, return saham. Adjusted nilai R Square adalah 0,989, maka dapat dilakukan 98,9\% variabel Return on Assets, Return on Equity, Laba Per Saham, dan Economic Value Added dapat dijelaskan oleh variabel return saham sedangkan 1,1\% sisanya dijelaskan oleh variabel lain.
\end{abstract}

\begin{abstract}
Iwin Arnova; This study aimed to determine the effect of Return on Assets, Return on Equity, Earnings Per Share, and Economic Value Added to stock return. This study is still condicted regards different result of various research. The research was conducted using secondary data. The population in this study are all manufacturing companies listed on the Indonesia Stock Exchange (IDX) of the year 2008-2011. The sampling method applies purposive sampling technique. On 48 samples. The data is analysis uses multiple regression analysis. The results of the regression analysis showed that the return on assets have a positive and significant effect on stock returns. Return on Equity and Earnings Per Share has no effect on stock returns, while the Economic Value Added negatively affect, stock returns. Adjusted R Square value is 0.989, it can be condud 98.9\% variable Return on Assets, Return on Equity, Earnings Per Share, and Economic Value Added can be explained by the variable stock returns while the remaining $1.1 \%$ is explained by other variables.
\end{abstract}

\section{Keywords: Stock Return, Return on Assets, Return on Equity, Earnings per Share, Economic Value Added.}

\section{PENDAHULUAN}

Perusahaan didirikan dengan tujuan mempertahankan eksistensinya dengan upaya menciptakan laba, menciptakan pelanggan, dan menjalankan upaya pengembangan dengan memusatkan perhatian pada kebutuhan masyarakat dalam hal produk yang diinginkan, kuantitas, harga, waktu pelayanan, kegunaan produk, dan sebagainya. Tujuan lainnya, perusahaan diharapkan untuk memperhatikan keinginan investor, karyawan, penyedia faktorfaktor produksi, maupun masyarakat luas. Investor memerlukan informasi keuangan untuk melakukan penilaian perusahaan. Kriteria yang pada umumnya digunakan dalam penilaian tersebut adalah pendekatan analisis fundamental. Pendekatan ini berlandaskan prinsip bahwa 
sebab mendasar yang menimbulkan gerak harga saham adalah antisipasi perubahan dalam penjualan atau laba (Rousana, 1997).

Penilaian atau pengukuran kinerja perusahaan dengan rasio-rasio tertentu yang tidak memasukkan faktor biaya modal (cost of equity), merupakan pendekatan dalam menilai perusahaan. Pendekatan ini berdasarkan pada angka yang tertera dalam laporan keuangan suatu perusahaan yang dipublikasikan. Angka yang tertera dalam satu laporan keuangan maupun antar dua laporan keuangan akan membentuk suatu rasio (Atmaja:2002).

Menurut Santoso (2008) EVA dipopulerkan oleh G. Bennett Steward, dalam bukunya The Quest For Value tahun 1991. Sejak itu lebih dari 300 perusahaan di Dunia mengadopsi EVA. Tahun 2006 dan 2007 majalah Swa telah melakukan pemeringkatan perusahaan-perusahaan yang go public berdasar pada EVA yang diperoleh. Pemeringkatan tersebut dilakukan untuk melihat perusahaan-perusahaan yang mempunyai kinerja keuangan berdasar EVA yang dihasilkan.

Penerapan EVA sebagai pengukur kinerja menjadi kian relevan karena mencerminkan kemampuan perusahaan dalam menciptakan nilai tambah sekaligus mengeliminasi rekayasa keuangan. Lebih menarik lagi adalah bahwa EVA merupakan pengukuran kinerja yang memuat total faktor kinerja karena memasukkan semua unsur dalam laporan laba/rugi dan neraca perusahaan. Hal ini berbeda dengan pendekatan rasio yang biasanya hanya memfokuskan pada salah satu ukuran pertumbuhan seperti pertumbuhan pendapatan (ROA). Pengukuran ROA dianggap beresiko karena jika permasalahan berfokus pada pertumbuhan yang besar saja tanpa memperhatikan tingkat pengembalian yang tinggi dari biaya modal, akan menghancurkan nilai perusahaan. Sebaliknya jika hanya berfokus mengemukakan ROA saja manajemen cenderung menekan aset dan mengerem investasi. Akibatnya investor akan enggan untuk melakukan investasi meskipun investasi tersebut menguntungkan perusahaan dalam jangka panjang.

Nilai perusahaan pada dasarnya dapat diukur dengan harga pasar saham perusahaan karena harga pasar saham perusahaan mencerminkan penilaian investor secara keseluruhan atas setiap ekuitas yang dimiliki. Harga pasar saham menunjukkan penilaian sentral dari seluruh pelaku pasar, harga pasar saham bertindak sebagai barometer kinerja manajemen perusahaan. Jika nilai suatu perusahaan dapat diproksikan dengan harga saham maka memaksimumkan nilai pasar perusahaan sama dengan memaksimumkan harga pasar saham. Kinerja perusahaan menentukan tinggi rendahnya harga saham di pasar saham. Untuk itu diperlukan suatu analisa menyeluruh atas keadaan keuangan perusahaan tersebut untuk memperoleh return yang maksimal (Atmaja, 2002).

Penelitian tentang hubungan antara rasio keuangan dan EVA terhadap return saham telah banyak dilakukan. Pada umumya mereka menemukan hasil temuan yang berbeda dikarenakan sampel dan periode penelitian yang berbeda. Berdasarkan penelitian Lehn \& Makhija (1996) untuk mengetahui seberapa baik pengaruh ROE, EPS dan EVA terhadap return saham, hasilnya menunjukkan EVA sangat signifikan terhadap return saham sebesar 50\%, sedangkan ROE sebesar 25\% dan EPS hanya 18\%. Penelitian Uyemura (1996) menggunakan sampel dari 100 Bank terbesar Amerika Serikat untuk periode 1986-1995 untuk menguji korelasi EVA dengan ROA, ROE terhadap return saham. Hasil analisis regresi mereka didapatkan EVA sebesar 40\%, ROA hanya $13 \%$, dan ROE hanya $10 \%$.

Berdasarkan hasil analisis tersebut jelas menunjukkan bahwa EVA adalah ukuran yang berkorelasi yang terbaik sejauh ini dengan menciptakan kekayaan pemegang saham. Meskipun EVA mempunyai kelebihan dibandingkan dengan pengukur kinerja tradisional, tidak semua kalangan mengakuinya. Beberapa penelitian yang dilakukan juga menunjukkan bahwa EVA bukan merupakan pengukur kinerja perusahaan yang terbaik dihubungkan dengan harga saham maupun return saham.

Menggunakan rumus perhitungan EVA versi Stern Steward, hasil penelitian Dodd dan Chen (1996) menyebutkan bahwa EVA hanya mampu menunjukkan hubungan dengan return saham sebesar 20,2\% sedangkan ROA menunjukkan hubungan yang lebih tinggi yaitu 24,5\%. 
Hasil penelitian Dodd dan Chen tersebut menunjukkan bahwa ROA mempunyai hubungan yang lebih kuat dibandingkan dengan EVA. Chendrawati dan Hartono (1997) juga menguji apakah ROA atau EVA yang mempunyai hubungan paling kuat dengan return saham. Hasilnya menunjukkan bahwa ROA mempunyai hubungan paling kuat dengan return saham (70\%) dan signifikan pada taraf uji two tailed dibandingkan dengan EVA yang hanya sekitar $10 \%$.

Penelitian Sasongko dan Wulandari (2006) menunjukkan bahwa variabel EPS berpengaruh terhadap harga saham, sedangkan variabel ROA dan EVA tidak berpengaruh signifikan terhadap harga saham. Penelitian Kusumawati dan Susilowati (2004) menggunakan sampel sebanyak 10 perusahaan manufaktur di Bursa Efek Jakarta selama periode 1998-2001 menunjukkan hasil bahwa variabel Earning per Share (EPS), dan Return on Asset (ROA) berpengaruh terhadap return saham dengan menggunakan analisis regresi secara serentak (simultan) menunjukkan variabel-variabel tersebut mempunyai pengaruh signifikan terhadap return saham. Sedangkan dari hasil analisis regresi secara parsial menunjukkan bahwa hanya Earning per Share (EPS) yang berpengaruh paling signifikan terhadap return saham dengan nilai koefisien yang tertinggi dibandingkan dengan keempat variabel lainnya, yaitu sebesar 0,666. Berdasarkan penelitian yang selama ini dilakukan oleh peneliti-peneliti terdahulu tentang pengaruh ROA, ROE, EPS, dan EVA terhadap return saham yang hasilnya kontradiksi satu dengan yang lainnya dan didorong dengan kelebihan metode EVA yang ditawarkan oleh Stewart Co, maka penelitian ini termotivasi untuk menguji kembali metode ROA, ROE, EPS, dan EVA terhadap return saham.

\section{KAJIAN TEORI DAN PENGEMBANGAN HIPOTESIS Teori Pasar Modal Efisien}

Menurut Husnan (2005:260) pasar yang efisien adalah "pasar yang harga sekuritassekuritasnya mencerminkan semua informasi yang relevan". Efisiensi tersebut tercipta karena banyaknya analis sekuritas yang melakukan kegiatan mereka, dan persaingan antar mereka. Bagi perusahaan, pasar yang efisien berarti rekayasa laporan keuangan tidak mampu meningkatkan harga saham apabila rekayasa tersebut tidak mempunyai dampak terhadap arus kas perusahaan.

Jika pasar bereaksi dengan cepat dan akurat untuk mencapai harga keseimbangan baru yang sepenuhnya mencerminkan informasi yang tersedia, maka kondisi pasar seperti ini disebut dengan pasar efisien. Pasar modal dikatakan efisien bila informasi dapat diperoleh dengan mudah dan murah oleh para pemodal, sehingga semua informasi yang relevan dan terpercaya telah tercermin dalam harga-harga saham. Pada umumnya situasi pasar modal efisien menunjukkan hubungan antara harga pasar dan bentuk pasar. Pengertian harga pasar dalam hal ini adalah harga saham yang ditentukan dan dibentuk oleh mekanisme pasar modal. Sedang bentuk mekanisme pasar modal tidak mudah untuk didefinisikan, mengingat hal itu meliputi sejumlah aktivitas (kejadian) yang berpengaruh pada beberapa keadaan. Adanya berbagai situasi maupun kondisi yang berbeda diantara Negara yang satu dengan yang lainnya, menyebabkan efisiensi pasar pada suatu Negara akan berbeda dengan Negara lain (Hartono, 2003:369).

\section{Bentuk Efisiensi Pasar Secara Informasi}

Kunci utama untuk mengukur pasar yang efisien adalah hubungan antara harga sekuritas dengan informasi. Menurut Hartono (2003:375) ada tiga macam bentuk utama dari efisiensi pasar berdasarkan ketiga macam bentuk informasi, yaitu informasi masa lalu, informasi sekarang yang sedang dipublikasikan dan informasi privat, sebagai berikut:

1. Efisiensi pasar bentuk lemah (week form)

Pasar dikatakan efisien dalam bentuk lemah jika harga-harga dari sekuritas tercermin secara penuh (fully reflect) informasi masa lalu. Informasi masa lalu ini merupakan informasi yang sudah terjadi. Bentuk efisiensi pasar secara lemah ini berkaitan dengan 
teori langkah acak (random walk theory) yang menyatakan bahwa data masa lalu tidak berhubungan dengan nilai sekarang. Jika pasar efisiensi secara bentuk lemah, maka nilainilai masa lalu tidak dapat digunakan untuk memprediksi harga sekarang. Ini berarti bahwa untuk pasar yang efisien bentuk lemah, investor tidak dapat menggunakan informasi masa lalu untuk mendapatkan keuntungan yang tidak normal.

2. Efisiensi pasar bentuk setengah kuat (semistrong form)

Pasar dikatakan efisien setengah kuat jika harga-harga sekuritas secara penuh mencerminkan (fully reflect) semua informasi yang dipublikasikan (all publicly available information) termasuk informasi yang berbeda di laporan-laporan keuangan perusahaan emiten. Informasi yang dipublikasikan dapat berupa:

1. Informasi yang dipublikasikan yang hanya mempengaruhi harga sekuritas dari perusahaan yang mempublikasikan informasi tersebut.

2. Informasi yang dipublikasikan yang mempengaruhi harga-harga sekuritas sejumlah perusahaan.

3. Informasi yang dipublikasikan yang mempengaruhi harga-harga sekuritas semua perusahaan yang tedaftar di pasar saham. Jika pasar efisien dalam bentuk setengah kuat, maka tidak ada investor atau grup dari investor yang dapat menggunakan informasi yang dipublikasikan untuk mendapatkan keuntungan tidak normal dalam jangka waktu yang lama.

3. Efisiensi pasar bentuk kuat (strong form)

Pasar dikatakan efisien dalam bentuk kuat jika harga-harga sekuritas sacara penuh mencerminkan (fully reflect) semua informasi yang tersedia termasuk informasi yang privat. Jika pasar efisien dalam bentuk ini, maka tidak ada individual investor atau grup dari investor yang dapat memperolah keuntungan tidak normal (abnormal return) karena mempunyai informasi privat.

\section{Bentuk Efisiensi Pasar Secara Keputusan}

Menurut Hartono (2003:381) Efisiensi pasar dilihat "berdasarkan kemampuan pelaku pasar dalam mengelola informasi untuk pengambilan keputusan". Efisiensi pasar secara keputusan juga merupakan efisiensi pasar bentuk setengah kuat yang didasarkan pada informasi yang didistribusikan. Efisiensi pasar secara informasi (informationally efficient market) hanya didistribusikan dengan mempertimbangkan dua buah faktor, yaitu ketersediaan informasi dan kemampuan pelaku pasar. Karena melibatkan lebih banyak faktor dalam menetukan pasar yang efisien, suatu pasar yang efisien secara keputusan merupakan efisien pasar bentuk setengah kuat secara informasi. Dengan demikian efisiensi pasar secara keputusan dapat ditambahkan di pembagian efisiensi pasar.

Pasar yang efisien secara informasi belum tentu efisien secara keputusan. Sebagai contoh misalnya adalah pengumuman pembayaran dividen yang naik dari nilai dividen periode sebelumnya dan informasi ini tersedia untuk semua pelaku pasar pada saat yang bersamaan. Umunya perusahaan emiten menggunakan pembayaran dividen sebagai sinyal kepada pelaku pasar. Dengan meningkatkan nilai dividen yang dibayar, perusahaan emiten mencoba memberi sinyal bahwa perusahaan mempunyai prospek yang baik di masa depan, sehingga mampu meningkatkan pembayaran dividen. Pelaku pasar yang kurang mampu menganalisis informasi akan menerima informasi peningkatan dividen ini begitu saja sebagai sinyal yang baik tanpa menganalisisnya lebih lanjut dan harga sekuritas akan mencerminkan informasi kabar baik secara penuh. Secara definisi, ini berarti pasar sudah efisien bantuk setengah kuat secara informasi. 


\section{Teori Signal}

Menurut Jama'an (2008:54) Signaling Theory mengemukakan tentang bagaimana seharusnya sebuah perusahaan memberikan sinyal kepada pengguna laporan keuangan. Sinyal ini berupa informasi mengenai apa yang sudah dilakukan oleh manajemen untuk merealisasikan keinginan pemilik. Sinyal dapat berupa promosi atau informasi lain yang menyatakan bahwa perusahaan tersebut lebih baik daripada perusahaan lain. Teori sinyal menjelaskan bahwa pemberian sinyal dilakukan oleh manajer untuk mengurangi asimetri informasi. Manajer memberikan informasi melalui laporan keuangan bahwa mereka menerapkan kebijakan akuntansi konservatisme yang menghasilkan laba yang lebih berkualitas karena prinsip ini mencegah perusahaan melakukan tindakan membesar-besarkan laba dan membantu pengguna laporan keuangan dengan menyajikan laba dan aktiva yang tidak overstate.

Menurut Kabu (2011:13) kualitas keputusan investor dipengaruhi oleh kualitas informasi yang diungkapkan perusahaan dalam laporan keuangan. Kualitas informasi tersebut bertujuan untuk mengurangi asimetri informasi yang timbul ketika manajer lebih mengetahui informasi internal dan prospek perusahaan di masa mendatang dibanding pihak eksternal perusahaan. Informasi yang berupa pemberian peringkat obligasi perusahaan yang dipublikasikan diharapkan dapat menjadi sinyal kondisi keuangan perusahaan tertentu dan menggambarkan kemungkinan yang terjadi terkait dengan utang yang dimiliki.

Teori signal juga dapat membantu pihak perusahaan (agent), pemilik (prinsipal), dan pihak luar perusahaan mengurangi asimetri informasi dengan menghasilkan kualitas atau integritas informasi laporan keuangan. Untuk memastikan pihak-pihak yang berkepentingan meyakini keandalan informasi keuangan yang disampaikan pihak perusahaan (agent), perlu mendapatkan opini dari pihak lain yang bebas memberikan pendapat tentang laporan keuangan (Jama'an, 2008:55).

\section{Pengukuran Kinerja}

Menurut Behn (2003:23) Pengukuran kinerja adalah "Proses di mana organisasi menetapkan parameter hasil untuk dicapai oleh program investasi, dan akusisi yang dilakukan. Proses pengukuran kinerja seringkali membutuhkan penggunaan bukti statistik untuk menentukan tingkat kemajuan suatu organisasi dalam meraih tujuannya. Tujuan mendasar di balik dilakukannya pengukuran adalah untuk meningkatkan kinerja secara umum.

Koesno (1990:45) menyatakan bahwa "kinerja perusahaan dapat diukur dari beberapa factor", yaitu book value per share, Earning Per Share, volatilitas saham, faktor intern, seperti profit, tingkat efisien, leverange, kualitas manajemen, tingkat aktivitas/perdagangan., popularitas merek, risiko usaha. Faktor ekstern seperti suku bunga deposito, tingkat inflasi, pajak dividen, dan kekuatan pesaing.

Purnomo (1998:45) menyatakan bahwa "rasio keuangan merupakan pengukur kinerja keuangan yang lebih fundamental dalam menjelaskan beberapa kekuatan dan kelemahan keuangan perusahaan". Rasio keuangan biasanya dapat digunakan untuk menjawab pertanyaan-pertanyaan seperti bagaimana likuiditas perusahaan, apakah manajemen menghasilkan laba yang memadai dari penggunaan aset perusahaan, dan bagaimana perusahaan mendanai aset-asetnya, dan apakah para pemegang saham menerima penghasilan yang memadai dari investasi yang telah mereka lakukan. Rasio-rasio tersebut biasanya dicantumkan dalam laporan keuangan yang dipublikasikan.

Menurut Warsono (2001:26) metode yang digunakan dalam mengukur kinerja keuangan perusahaan selama ini, antara lain:

a. Metode Rasio Keuangan, merupakan alat yang digunakan untuk menilai kinerja perusahaan yang menekankan operasi keuangan yaitu: rasio likuiditas, rasio leverage, rasio profitabilitas dan rasio aktivitas. 
b. Metode Economic Value Added (EVA), digunakan dalam menilai kinerja perusahaan yang memfokuskan pada penerapan nilai, dan hanya bisa menilai proses dalam periode 1 tahun, dengan kata lain EVA merupakan pengukuran pendapatan sisa (residul income) yang mengurangkan biaya modal terhadap laba operasi.

\section{Pengukuran Kinerja dengan Rasio Keuangan}

Penilaian atau pengukuran kinerja perusahaan dengan rasio-rasio tertentu yang tidak memasukkan faktor biaya modal (cost of equity), merupakan pendekatan dalam menilai perusahaan. Pendekatan ini berdasarkan pada angka yang tertera dalam laporan keuangan suatu perusahaan yang dipublikasikan. Angka yang tertera dalam satu laporan keuangan maupun antar dua laporan keuangan akan membentuk suatu rasio (Atmaja:2002).

Menurut Prastowo (1995) rasio keuangan dikelompokkan menjadi rasio likuiditas (quick ratio, current ratio, dan lain-lain), rasio aktivitas (rata-rata umur piutang, perputaran persediaan, perputaran aktiva tetap, perputaran total aktiva, dan lain-lain), rasio solvabilitas (total utang terhadap total aset, times intered earned, fixed charged coverage, dan lain-lain), rasio profitabilitas (profit margin, ROA, ROE, dan lain-lain), dan rasio pasar (PER, dividend yield, divident payout ratio, EPS, dan lain-lain).

Chen dan Dodd (1996) menyatakan bahwa laporan keuangan lebih menekankan pada laba akuntansi (accounting earning) meskipun disadari bahwa teori penilaian ekuitas lebih mementingkan future cash flow dalam menentukan return saham suatu peusahaan. Argument yang mendasari hal tersebut adalah informasi tentang earning (laba) merupakan indikator lebih baik bagi kemampuan perusahaan dalam menghasilkan aliran kas sekarang dan masa datang dibandingkan dengan informasi tentang penerimaan dan pengeluaran kas. Beberapa model penilaian dikembangkan oleh komunitas investasi dengan memasukkan laba sebagai input utama, sebagai contoh EPS menjadi alat analisis yang digunakan sebagai indikator keuangan di pasar modal.

\section{Return On Assets (ROA)}

Return On Assets (ROA) disebut juga rentabilitas ekonomi digunakan untuk mengukur kemampuan perusahaan menghasilkan laba pada masa lalu yang kemudian diproyeksikan ke masa depan untuk melihat kemampuan perusahaan menghasilkan laba dimasa mendatang (Riyanto, 2001:36). ROA merupakan suatu indikator keuangan yang menggambarkan kemampuan perusahaan dalam menghasilkan laba atas total aset yang dimiliki perusahaan. Rasio ini mengukur tingkat pengembalian investasi yang telah dilakukan perusahaan dengan menggunakan seluruh aktiva yang dimiliknya. Semakin tinggi ROA semakin tinggi keuntungan. Semakin tinggi keuntungan yang dihasilkan perusahaan akan menjadikan investor tertarik akan saham, aktiva dan investasi tertentu dari pemilik perusahaan. Banyaknya investor yang berminat untuk berinvestasi maka akan menyebabkan naiknya harga saham yang mempengaruhi juga terhadap return yang diterima oleh investor.

Menurut Lisa (1999) keunggulan ROA adalah:

1. ROA merupakan pengukuran yang komprehensif dimana seluruhnya mempengaruhi laporan keuangan yang tercermin dari rasio ini.

2. ROA mudah dihitung, dipahami, dan sangat berarti dalam nilai absolut.

3. ROA merupakan denominator yang dapat diterapkan pada setiap unit organisasi yang bertanggung jawab terhadap profitabilitas dan unit usaha.

Disamping beberapa keunggulan diatas ROA juga memiliki kelemahan yaitu (Lisa, 1999):

1. Pengukuran kinerja dengan menggunakan ROA membuat manajer divisi memiliki kecenderungan untuk melewatkan project-project yang menurunkan divisional ROA, 
meskipun sebenarnya proyek-proyek tersebut dapat meningkatkan tingkat keuntungan perusahaan secara keseluruhan.

2. Manajemen juga cenderung untuk berfokus pada tujuan jangka pendek dan bukan tujuan jangka panjang.

3. Sebuah project dalam ROA dapat meningkatkan tujuan jangka pendek, tetapi project tersebut mempunyai konsekuensi negatif dalam jangka panjang, yang berupa pemutusan beberapa tenaga penjualan, pengurangan budget pemasaran, dan penggunaan bahan baku yang relatif murah sehingga menurunkan kualitas produk dalam jangka panjang.

\section{Return On Equity (ROE)}

Return on Equity (ROE) disebut juga dengan istilah rentabilitas modal sendiri (Husnan, 2004:56). Return on Equity merupakan kemampuan suatu perusahaan dengan modal sendiri yang bekerja di dalamnya untuk menghasilkan keuntungan (Riyanto, 2001:44). Salah satu alasan utama perusahaan beroperasi adalah menghasilkan laba yang bermanfaat bagi pemegang saham, ukuran dari keberhasilan pencapaian alasan ini adalah angka ROE berhasil di capai. Semakin besar ROE mencerminkan kemampuan perusahaan dalam menghasilkan keuntungan bagi pemegang saham. Laba yang diperhitungkan untuk menghitung rentabilitas modal sendiri (ROE) adalah laba usaha setelah dikurangi dengan bunga modal asing dan pajak perseroan atau income tax. Sedangkan modal sendiri yang diperhitungkan hanyalah modal sendiri yang bekerja di dalam perusahaan.

Menurut Bodie, Kane and Marcus (2002) Return on Equity (ROE) yang merupakan perbandingan antara laba bersih dengan ekuitas ini merupakan salah satu dari dua faktor dasar dalam menentukan pertumbuhan tingkat pendapatan perusahaan. Ada dua sisi dalam menggunakan ROE, kadang-kadang diasumsikan bahwa ROE yang akan datang merupakan perkiraan dari ROE yang lalu. Tetapi ROE yang tinggi pada masa yang lalu tidak menjamin ROE yang akan datang masih tetap tinggi. Penurunan ROE merupakan bukti bahwa investasi baru pada perusahaan tersebut menghasilkan ROE yang lebih rendah dari investasi lama. Hal paling penting dari para analis adalah tidak perlu menerima nilai historis sebagai indikator dari nilai yang akan datang.

\section{Earning Per Share (EPS)}

Earning per share (EPS) adalah laba perlembar saham yang merupakan indikator yang secara ringkas menyajikan kinerja perusahaan yang dinyatakan dengan laba (Darmadji, 2006:67). Makin tinggi nilai EPS semakin besar laba yang disediakan untuk pemegang saham (Darmadji, 2006:54). Hal ini akan berakibat dengan meningkatnya laba maka harga saham cendrung naik dan memunkinkan terjadinya kenaikan return saham. Namun demikian Steward (dalam Chen \& Dodd:1996) mengkritik bahwa pendekatan rasio keuangan merupakan pengukuran yang gagal memasukkan total cost of capital. Suatu pengukuran seharusnya tidak dipengaruhi oleh ketentuan akuntansi yang berbasis akrual. Sejak itu EVA diakui sebagai pengukur kinerja perusahaan yang baru dan inovatif karena dapat mengkoreksi dua tipe kesalahan yang dimiliki oleh accounting earning.

Umumnya perhitungan EPS menggunakan basis laporan keuangan akhir tahun. Namun dapat pula menggunakan laporan keuangan tengah tahunan. Dalam praktiknya, EPS dihitung dengan membagi laba bersih dengan jumlah rata-rata tertimbang dari jumlah lembar saham biasa yang beredar sepanjang tahun. Jumlah rata-rata diperlukan dalam perhitungan karena jumlah saham yang beredar selam satu tahun tidak selalu tetap, atau dengan kata lain, jumlah saham yang beredar dapat berubah. 


\section{Pengukuran Kinerja dengan Pendekatan EVA}

Istilah EVA pertama kali dipopulerkan oleh Stern Steward Manajemen Seevice yang merupakan perusahaan konsultan dari Amerika Serikat pada tahun 1980-an. EVA telah lama dikenal oleh para ekonom sebagai aconomic profit, yaitu nilai profit yang melebihi (kurang dari) tingkat pengembalian minimum yang bisa diperoleh oleh pemegang saham dan kreditor dengan berinvestasi di sekuritas lain yang mempunyai risiko sebanding (opportunity cost).

Menurut Sawir (2003:74) Economic Value Added (EVA) adalah "salah satu cara untuk menilai kinerja keuangan. Economic Value Added (EVA) merupakan indikator tentang adanya penambahan nilai dari suatu investasi". Hansen \& Mowen (2000:46) menyatakan EVA sebagai alat yang lebih baik dalam menilai kinerja manajer divisi dibandingkan dengan ROA. Pengukuran berdasarkan ROA, manajer divisi enggan melakukan investasi jika investasi akan menurunkan ROA divisi meskipun dapat menaikkan laba perusahaan secara keseluruhan.

EVA merupakan laba operasi setelah pajak (after tax operating income) dikurangi dengan total biaya modal (total cost of capital). Total biaya modal merupakan tingkat biaya modal dikalikan dengan total modal yang diinvestasikan (Utama, 1997:46). EVA merupakan perhitungan yang sederhana, mudah dipahami oleh kalangan non finansial tetapi cukup komperehensif. EVA merupakan selisih antara NOPAT (net operating profit after tax) dengan capital charge. Atau EVA = spread EVA, yaitu selisih antara ROIC (return on invested capital) dan WAAC (weight average cost of capital) dikalikan dengan invested capital.

Menurut Mirza (1999) Meskipun EVA memiliki beberapa keunggulan, namun teknik ini juga memiliki beberapa kelemahan. Kelemahan EVA antara lain:

1. Sulit menentukan biaya modal secara objektif. Hal ini disebabkan dana untuk investasi dapat berasal dari berbagai sumber dengan tingkat biaya modal yang berbeda-beda dan bahkan biaya modal mungkin merupakan biaya peluang.

2. EVA terlalu bertumpu pada keyakinan bahwa investor sangat mengandalkan pendekatan fundamental dalam mengkaji dan mengambil keputusan untuk menjual atau membeli saham tertentu, padahal faktor-faktor lain terkadang lebih dominan.

3. Konsep ini sangat tergantung pada trasparasi internal dalam perhitungan EVA secara tepat. Dalam kenyataannya seringkali perusahaan kurang trasparan dalam mengemukakan kondisi internalnya.

4. EVA jarang dipakai dalam praktik

5. EVA hanya mengukur salah satu keberhasilan bisnis.

Semakin banyak perusahaan yang menggunakan EVA sebagai suatu alat untuk mengukur kinerja perusahaan, khususnya untuk mengukur penciptaan nilai. Perusahaanperusahaan tersebut percaya bahwa penggunaan EVA akan membuat kepentingan manajer semakin sesuai dengan kepentingan pemilik modal. EVA mengukur besarnya nilai yang diciptakan oleh suatu perusahaan kerena berbeda dengan pengukuran akuntansi tradisional, EVA memperhitungkan biaya modal atas investasi yang dilakukan. Dengan diperhitungkannya biaya modal, EVA mengindikasikan seberapa jauh perusahaan telah menciptakan nilai bagi pemilik modal. Namun demikian, dalam prakteknya EVA dapat menimbulkan masalah, terutama kerena diperlukannya estimasi atas tingkat biaya modal. Untuk itu dalam menerapkan EVA, kita harus selalu memonitor dan mengevaluasi atas kewajaran tingkat biaya modal.

Menurut Steward and Co (2007) penilaian EVA dapat dinyatakan sebagai berikut:

1. Apabila EVA $>0$, berarti nilai EVA positif yang menunjukkan telah terjadi proses nilai tambah pada perusahaan.

2. Apabila EVA = 0 menunjukkan posisi impas atau Break Event Point.

3. Apabila EVA $<0$, yang berarti EVA negatif menunjukkan tidak terjadi proses nilai tambah. 


\section{Harga Saham}

Menurut Hartono (2000:69) Harga saham adalah "harga yang terjadi di pasar bursa pada waktu tertentu yang ditentukan oleh pelaku pasar yaitu permintaan dan penawaran pasar". Harga saham dipengaruhi oleh 4 aspek yaitu: pendapatan, dividen, aliran kas, dan pertumbuhan. Menurut Husnan \& Pudjiastuti (2004) saham atau sekuritas merupakan "secarik kertas yang menunjukkan hak pemilik kertas tersebut untuk memperoleh bagian dari prospek atau kekayaan perusahaan yang menerbitkan sekuritas tersebut dan berbagai kondisi untuk melaksanakan hak tersebut".

Menurut Hartono (2000:77) selembar saham mempunyai nilai atau harga dan dapat dibedakan menjadi 3(tiga), yaitu:

a. Harga Nominal

Harga yang tercantum dalam sertifikat saham yang ditetapkan oleh emiten untuk menilai setiap lembar saham yang dikeluarkan. Besarnya harga nominal memberikan arti penting saham karena deviden minimal biasanya ditetapkan berdasarkan nilai nominal.

b. Harga Perdana

Harga ini merupakan harga saat saham itu dicatat di bursa efek. Harga saham pada pasar perdana biasanya ditetapkan oleh penjamin emisi (underwriter) dan emiten. Dengan demikian akan diketahui berapa harga saham itu akan dijual kepada masyarakat biasanya untuk menentukan harga perdana.

c. Harga Pasar

Jika harga perdana merupakan harga jual dari perjanjian emisi kepada investor, maka harga pasar adalah harga jual dari investor yang satu dengan investor yang lain. Harga ini terjadi setelah saham tersebut dicatat di bursa. Transaksi di sini tidak lagi melibatkan emiten dan penjamin emisi harga, ini disebut sebagai harga di pasar sekunder dan harga inilah yang benar-benar mewakili harga perusahaan penerbitnya, karena transaksi di pasar sekunder, kecil sekali terjadi negosiasi harga investor dengan perusahaan penerbit. Harga yang setiap hari diumumkan di surat kabar atau media lain adalah harga pasar.

Hartono (2003:80) menyatakan bahwa mengetahui nilai pasar dan nilai intrinsik dari suatu saham, dapat digunakan untuk mengetahui saham-saham mana yang murah, tepat nilainya/wajar atau yang mahal. Nilai pasar yang lebih kecil dari nilai intrinsiknya menunjukkan bahwa saham tersebut dijual dengan harga yang murah (under valued), karena investor membayar saham tersebut lebih kecil dari yang seharusnya dia bayar. Bila nilai intrinsik saham sama dengan harga pasar maka harga saham tersebut adalah wajar/tepat nilai (correctly valued). Sedangkan jika nilai intrinsik lebih kecil dibandingkan dengan harga pasar, maka harga ditetapkan over valued.

\section{Return Saham}

Menurut Hartono (2001:109) "Return merupakan pengembalian hasil yang diperoleh dari suatu investasi". Return saham dibedakan menjadi dua, yaitu: return realisasi (realized return) dan return ekspektasi (expected return). Return realisasi merupakan return yang sudah terjadi yang dihitung berdasarkan data historis. Return realisasi ini penting dalam mengukur kinerja dalam perusahaan dan sebagai dasar penentuan return dan risiko di masa mendatang. Return ekspektasi merupakan return yang diharapkan di masa mendatang dan masih bersifat tidak pasti. Return yang diterima oleh investor di pasar modal dibedakan menjadi dua jenis yaitu current income (pendapatan lancar) dan capital gain/capital loss (keuntungan selisih harga). Current income adalah keuntungan yang didapat melalui pembayaran yang bersifat periodik seperti deviden. Keuntungan ini biasanya diterima dalam bentuk kas atau setara kas sehingga dapat diuangkan secara cepat. Misalnya deviden saham yang dibayarkan dalam bentuk saham yang bisa dikonversi menjadi uang kas dengan cara menjual saham yang diterimanya. 
Sedangkan capital gain (loss) merupakan selisih laba (rugi) yang dialami oleh pemegang saham karena harga saham sekarang relatif lebih tinggi (rendah) dibandingkan harga saham sebelumnya. Jika harga saham sekarang tinggi maka pemegang saham mengalami capital gain. Jika yang terjadi sebaliknya maka pemegang saham akan mengalami capital loss.

\section{Hipotesis}

$\mathrm{H}_{1}$ : ROA (Return On Asset) berpengaruh terhadap Return saham

$\mathrm{H}_{2}$ : ROE (Return On Asset) berpengaruh terhadap Return saham

$\mathrm{H}_{3}$ : EPS (Earning Per Share) berpengaruh terhadap Return saham

$\mathrm{H}_{4}$ : EVA (Economic Value Added) berpegaruh terhadap Return saham

\section{METODE PENELITIAN}

\section{Populasi dan Sampel}

Populasi pada penelitian ini adalah seluruh perusahaan manufaktur yang terdaftar di Bursa Efek Indonesia (BEI). Sampel pada penelitian ini diambil dengan menggunakan purposive sampling. Periodesasi penelitian tahun 2008-2011 (4 tahun) dipandang cukup mewakili kondisi keuangan perusahaan-perusahaan yang ada di BEI.

\section{Operasional dan Pengukuran Variabel}

\section{Return On Asset (ROA)}

Return On Assets (ROA) disebut juga rentabilitas ekonomi digunakan untuk mengukur kemampuan perusahaan menghasilkan laba pada masa lalu yang kemudian diproyeksikan ke masa depan untuk melihat kemampuan perusahaan menghasilkan laba dimasa mendatang (Riyanto, 2001:36).

$$
\text { ROA }=\frac{\text { Net } \text { Pr ofit After Tax }}{\text { Total Asset }}
$$

\section{Return On Equity (ROE)}

Return on Equity merupakan kemampuan suatu perusahaan dengan modal sendiri yang bekerja di dalamnya untuk menghasilkan keuntungan (Riyanto, 2001: 44).

$$
\mathrm{ROE}=\frac{\text { laba bersih }}{\text { ekuitas }}
$$

\section{Earning Per Share (EPS)}

Earning per share adalah laba perlembar saham yang merupakan indikator yang secara ringkas menyajikan kinerja perusahaan yang dinyatakan dengan laba (Darmadji, 2006: 67).

$$
\mathrm{EPS}=\frac{\text { laba bersih }}{\text { total saham beredar }}
$$




\section{Economic Value Added (EVA)}

Economic Value Added (EVA) merupakan indikator tentang adanya perubahan nilai dari suatu investasi. EVA mengukur nilai tambah yang dihasilkan suatu perusahaan dengan cara mengurangi biaya modal yang timbul sebagai akibat investasi yang dilakukan (Sawir:2003).

EVA $=$ NOPAT $-($ WACC $\mathrm{x}$ IC)

NOPAT $=$ Net Operating Profit After Tax

WACC $=$ Weighted Average Cost of Capital

IC = Invested Capital (at the beginning of the year)

\section{Return Saham}

Pada penelitian ini harga saham dapat digunakan sebagai dasar untuk menghitung return bulanan. Harga saham yang digunakan dalam penelitian ini adalah harga saham bulanan. Return saham dihitung dengan rumus Indeks Harga Saham Individual:

$$
\begin{aligned}
& \mathrm{R}_{\mathrm{it}}=\frac{p_{i t}-p_{i t-1}}{p_{i t-1}} \\
& \mathrm{R}_{\mathrm{it}}=\text { return saham i periode } \mathrm{t} \\
& \mathrm{P}_{\mathrm{it}}=\text { harga saham penutupan saham i periode } \mathrm{t} \\
& \mathrm{P}_{\mathrm{it}-1}=\text { harga saham penutupan i pada periode sebelumnya }
\end{aligned}
$$

\section{Metode Analisis Data}

Metode analisis data yang digunakan dalam penelitian ini adalah analisis statistik deskriptif. Sebelum dilakukan pengujian regresi linier berganda terlebih dahulu dilakuka uji asumsi klasik meliputi uji normalitas, uji multikolinearitas, uji autokorelasi dan uji heterokedastisitas.

\section{Alat Analisis Regresi}

Penggunaan data sekunder yang bersifat kuantitatif dalam penelitian ini mengarahkan pada metode kuantitatif dengan menggunakan alat analisis regresi berganda atau multiple regression karena terdapat lebih dari satu variabel independen. Persamaan regresi berganda tersebut dirumuskan sebagai berikut:

$$
\begin{aligned}
& \mathrm{Y}=\mathrm{a}+\mathrm{b} 1 \mathrm{ROA}+\mathrm{b} 2 \mathrm{ROE}+\mathrm{b} \text { EPS }+\mathrm{b} 4 \mathrm{EVA}+\mathrm{e} \\
& \mathrm{Y} \quad=\text { Return saham perusahaan } \\
& \mathrm{ROA}=\text { Return On Asset perusahaan } \\
& \mathrm{ROE}=\text { Return On Equity perusahaan } \\
& \mathrm{EPS} \quad=\text { Earning Per Share perusahaan } \\
& \mathrm{EVA}=\text { Economic Value Added perusahaan } \\
& \mathrm{a} \quad=\text { Koefisien konstanta } \\
& \mathrm{b} 1,2,3,4=\text { Koefisien regresi } \\
& \mathrm{e} \quad=\text { Variabel gangguan/error }
\end{aligned}
$$

\section{HASIL DAN PEMBAHASAN \\ Hasil Pengujian Hipotesis}

Pengujian hipotesis ini digunakan analisis regresi linear berganda. Analisis regresi linear berganda digunakan untuk mengetahui ada tidaknya pengaruh antara variabel ROA, EPS, dan EVA dengan variabel Return saham. Hasil pengujian dapat dilihat pada tabel 4.10. 
Tabel 2

Hasil Pengujian Hipotesis

\begin{tabular}{|c|c|c|c|c|c|}
\hline \multirow[b]{2}{*}{ Model } & \multicolumn{2}{|c|}{$\begin{array}{l}\text { Unstandardized } \\
\text { Coefficients }\end{array}$} & \multirow{2}{*}{\begin{tabular}{|c|}
$\begin{array}{c}\text { Standardized } \\
\text { Coefficients }\end{array}$ \\
Beta \\
\end{tabular}} & \multirow[b]{2}{*}{ t } & \multirow[b]{2}{*}{ Sig. } \\
\hline & B & Std. Error & & & \\
\hline 1 (Constant) & 0,693 & 0,019 & & 36,398 & 0,000 \\
\hline NNROA & 0,858 & 0,022 & 1,034 & 39,700 & 0,000 \\
\hline NNEPS & $-0,011$ & 0,021 & $-0,014$ & $-0,513$ & 0,608 \\
\hline NNEVA & $-0,038$ & 0,011 & $-0,039$ & $-3,575$ & 0,000 \\
\hline
\end{tabular}

a. Dependent Variable: NNReturn Saham

Sumber: Data Sekunder diolah, 2013

Persamaan regresinya adalah: Return saham $=0,693+0,858 \mathrm{ROA}+(-0,11) \mathrm{EPS}+(-0,038) \mathrm{EVA}$

\section{Hasil Pengujian Hipotesis 1 dan Pembahasan}

Hipotesis pertama menyatakan bahwa Return On Asset berpengarruh terhadap Return Saham. Hasil pengujian menunjukkan bahwa Return On Asset memiliki pengaruh terhadap Return saham. Adanya pengaruh ROA dapat dilihat dari $t_{\text {hitung }}(39,700)>t_{\text {tabel }}(-1,6555)$, berarti ROA berpengaruh terhadap return saham. Berdasarkan hasil tersebut dapat disimpulkan bahwa hipotesis pertama dalam penelitian ini diterima.

Return On Asset berpengaruh terhadap Return Saham, hal ini menunjukkan tingkat pengembalian investasi yang telah dilakukan perusahaan dengan menggunakan seluruh aktiva yang dimiliknya mendapatkan keuntungan. Return on Asset (ROA) salah satu teknik analisis keuangan yang bersifat menyeluruh atau komprehensif dengan mengukur efektivitas perusahaan dengan keseluruhan dana yang ditanamkan dalam aktiva yang akan digunakan untuk operasi perusahaan dalam menghasilkan keuntungan. Nilai ROA yang besar dalam penelitian ini, berarti sampel perusahaan yang digunakan mempunyai kinerja yang bagus dalam menghasilkan laba bersih untuk pengembalian total aktiva yang dimiliki.

Perusahaan mempunyai ROA yang tinggi maka perusahaan tersebut berpeluang besar dalam meningkatkan pertumbuhan laba, sehingga berpengaruh terhadap harga saham, yaitu harga saham akan naik dan return saham juga akan naik. Naiknya keuntungan pada perusahaan maka diperkirakan perusahaan mempunyai prospek yang baik di masa yang akan datang, sehingga nilai saham menjadi tinggi. Tingginya keuntungan yang dihasilkan perusahaan juga akan menjadikan investor tertarik akan saham, aktiva dan investasi tertentu dari pemilik perusahaan. Banyaknya investor yang berminat untuk berinvestasi maka akan menyebabkan naiknya Return saham yang diterima oleh investor.

\section{Hasil Pengujian Hipotesis 2 dan Pembahasan}

Hipotesis kedua menyatakan bahwa Return On Equity berpengaruh terhadap Return Saham. Sedangkan pada hipotesis kedua tidak bisa dilakukan pengujian untuk menunjukkan bahwa Return On Equity berpengaruh terhadap Return saham. Karena terdapat multikolinieritas pada variabel. Variabel ROE ter exluded dari model karena mempunyai VIF paling tinggi sebesar 72,40 sehingga variabel ROE tidak dapat diuji.

\section{Hasil Pengujian Hipotesis 3 dan Pembahasan}

Hipotesis ketiga menyatakan bahwa Earning Per Share berpengaruh terhadap Return Saham. Hasil pengujian menunjukkan bahwa Earning Per Share tidak berpengaruh terhadap 
Return saham. Hal ini dapat dilihat dari $t_{\text {hitung }}(-0,513)>t_{\text {tabel }}(-1,6555)$ berarti EPS tidak berpengaruh terhadap return saham. Berdasarkan hasil tersebut dapat disimpulkan bahwa hipotesis ketiga dalam penelitian ini ditolak.

Perusahaan dalam menjalankan aktivitasnya memerlukan dana yang cukup agar operasional perusahaan berjalan lancar. Perusahaan yang kekurangan dana akan mencari dana tersebut. Dana tersebut bisa diperoleh dengan cara memasukkan modal baru dari pemilik perusahaan atau dengan cara melakukan pinjamam ke pihak di luar perusahaan. Apabila perusahaan melakukan pinjaman kepada pihak luar perusahaan maka akan timbul utang sebagai konsekuensi dari pinjamannya tersebut dan berarti perusahaan telah melakukan financial leverage. Semakin besar utang maka financial leverage juga akan semakin besar. Berarti resiko yang dihadapi perusahaan akan semakin besar.

Meningkatnya penggunaan utang oleh perusahaan maka akan mengakibatkan aktiva perusahaan juga meningkat. Dengan meningkatnya aktiva perusahaan, maka diharapkan laba yang dihasilkan juga meningkat. Sehingga pengembalian atas ekuitas pemegang saham tinggi. Tetapi pada perusahaan sampel belum mampu menghasilkan laba bersih untuk pengembalian ekuitas pemegang saham.

Apabila penggunaan utang yang dilakukan oleh perusahaan turun maka total aktiva perusahaan menjadi turun. Dengan menurunnya aktiva perusahaan maka laba yang dihasilkan oleh perusahaan juga akan menurun. Saat laba bersih turun dan jumlah lembar biasa naik maka Earning Per Share akan turun. Ketidak mampuan perusahaan untuk mendistribusikan pendapatan kepada pemegang sahamnya, mencerminkan semakin kecil keberhasilan usaha yang dilakukannya, sehingga pengembalian yang akan diterima investor rendah. Earning Per Share yang rendah, menunjukkan bahwa kinerja perusahaan tersebut termasuk buruk sehingga tidak dapat meningkatkan citranya dikalangan investor. Maka investor tidak tertarik untuk membeli saham tersebut dan hal itu menyebabkan return saham cenderung menurun.

Rendahnya nilai Earning Per Share menunjukkan kinerja perusahaan sampel tidak baik dalam mengelola sumber dana pembiayaan operasional secara efektif untuk menghasilkan laba bersih (profitabilitas meningkat). Jadi dapat dikatakan bahwa selain kurang memperhatikan efektivitas manajemen dalam mengelola investasi yang dimiliki perusahaan, investor juga kurang memperhatikan kinerja manajemen yang mampu mengelola sumber dana pembiayaan operasional secara, efektif untuk menciptakan laba.

Tidak ada hubungan antara Earning Per Share terhadap Return saham disebabkan oleh berbagai faktor, antara lain: perbedaan teknis perhitungan, ukuran perusahaan, kondisi pasar uang Indonesia, adanya faktor internal selain fundamental ekonomi, suku bunga deposito, devaluasi, pertumbuhan ekonomi, pengeluaran pemerintah dan jumlah uang beredar, penjualan, pertumbuhan penjualan, biaya, deviden tunai, kondisi sosial, politik, dan ekonomi.

\section{Hasil Pengujian Hipotesis 4 dan Pembahasan}

Hipotesis keempat menyatakan bahwa Economic Value Added berpengaruh terhadap Return Saham. Hasil pengujian menunjukkan bahwa Economic Value Added memiliki pengaruh negatif terhadap Return saham. Hal ini dapat dilihat dari $t_{\text {hitung }}(-3,575)>t_{\text {tabel }}(-1,6555)$, berarti EVA berpengaruh terhadap return saham. Berdasarkan hasil tersebut dapat disimpulkan bahwa hipotesis keempat dalam penelitian ini diterima.

Hubungan antara Economic Value Added dengan return saham pada penelitian ini bersifat negatif (tidak searah). Dimana kenaikan nilai EVA tidak diikuti dengan kenaikan return saham, begitu pula penurunan nilai EVA tidak diikuti dengan penurunan return saham. Apabila nilai EVA naik maka return saham turun. Sebaliknya, apabila nilai EVA turun maka return saham naik.

Perusahaan-perusahaan sampel, menghasilkan nilai EVA yang negatif untuk periode pengamatan 2008-2011. Hal ini berarti jika Economic Value Added naik maka return saham akan turun. Economic Value Added tahun 2008-2011 menghasilkan laba negatif yang menunjukkan bahwa pada tahun tersebut arti bahwa perusahaan tidak dapat menciptakan nilai tambah 
ekonomi, artinya laba bersih yang dihasilkan tidak mampu menutupi biaya modal atas ekuitas yang telah dikeluarkan oleh perusahaan.

Economic Value Added tahun 2008-2011 menghasilkan laba negatif. Hal ini juga dikarenakan faktor perekonomian Indonesia tahun 2008-2011 tengah mengalami krisis keuangan global. Dimana dampak negatif dari krisis global, antara lain sebagai berikut: menurunnya kinerja neraca pembayaran, tekanan pada nilai tukar rupiah, dorongan pada laju inflasi. Laba negatif menunjukkan bahwa manajemen tidak mampu menjalankan tugasnya dengan baik. Suatu perusahaan publik yang menghasilkan nilai Economic Value Added negatif meskipun mampu membukukan laba bersih yang tinggi sekalipun, berarti perusahaan ini belum mampu menghasilkan tingkat pengembalian modal yang sepadan untuk menutup resiko dan biaya investasi yang ditanamkan pemilik modal (investor). Semakin tinggi tingkat resiko investasi, semakin tinggi pula tingkat kembalian (pendapatan) yang dituntut investor. Jika Return On asset, Return on Equity, Earning Per Share berhenti pada laba (return) yang diraih, EVA mengurangi laba dengan biaya modal sehingga manajemen perusahaan dituntut untuk mampu memilih investasi dengan tingkat kembalian optimum dan dengan tingkat resiko minimum. Sehingga Economic Value Added berpengaruh negatif pada Return saham.

\section{PENUTUP \\ Kesimpulan}

Berdasarkan hasil analisis data dan pembahasan pada bab sebelumnya, maka kesimpulan pada penelitian ini sebagai berikut:

1. Hasil analisis regresi linear berganda menunjukkan bahwa Return On Asset, Earning Per Share dan Economic Value Added secara simultan berpengaruh terhadap Return saham.

2. Variabel Return On Equity tidak bisa dilakukan pengujian karena terdapat gejala multikolinearitas dan ter exlude dari model regresi.

3. Hasil analisis regresi linear berganda menunjukkan bahwa Return On Asset berpengaruh terhadap Return saham

4. Hasil analisis regresi linear berganda menunjukkan bahwa Earning Per Share tidak berpengaruh terhadap Return saham.

5. Hasil analisis regresi linear berganda menunjukkan bahwa Economic Value Added berpengaruh negatif terhadap Return saham.

\section{Keterbatasan}

Penelitian ini hanya membahas pengaruh variabel Return On Asset, Return On Equity, Earning Per Share dan Economic Value Added terhadap Return saham. Penelitian ini hanya memfokuskan pada perusahaan manufaktur periode 2008-2011

\section{Saran}

Berdasarkan hasil analisis yang diperoleh dalam penelitian ini, dapat diberikan saran sebagai berikut:

1. Untuk perusahaan manufaktur yang menjadi sampel sebanyak 48 perusahaan sebaiknya dapat terus menjaga kinerja keuangannya supaya dapat terus berkembang dan menarik lebih banyak investor.

2. Untuk Investor, penulis menyarankan agar melakukan analisa terlebih dahulu dalam membeli maupun menjual sahamnya, dimana analisa ini dapat dilihat dalam bentuk analisa laporan keuangan, terhadap rasio keuangan, resiko dari saham tersebut dan return dari saham yang akan diinvestasikan. Selain dilihat dari kinerja perusahaan, sumber-sumber 
informasi untuk analisis saham dapat melalui rekan-rekan sesama investor, berita di media masa baik cetak maupun elektronik.

3. Untuk penelitian selanjutnya sebaiknya periode penelitian dan sampel yang digunakan ditambah dan diperluas ke beberapa sektor perusahaan sehingga menghasilkan informasi yang lebih akurat.

\section{DAFTAR PUSTAKA}

Atmaja, Setia. EVA, VBM dan investor, SWA No.24/XVIII. 14 Oktober-4 November 2002: 34-36.

Behn, Robert D. Why Meansure Performance. (2003). Different Purpose Require Different Meansure. (online). (diakses 2 Januari 2013). Teredia di www: http://id.wikipedia.org/wiki/pengukuran kinerja.

Bodie, Kane, Marcus. 2002. Invesment. Buku Satu. Jakarta: Salemba Empat.

Chen, S. dan J.L. Dodd. 1996. Economic Value Added (EVA): an Empirical Examination of a New Corporate Performance Meansure. Journal of Manajerial Issues, Fall: 318-333.

Darmadji, T \& Fakhruddin, H. M. 2006. Pasar Modal di Indonesia. Edisi 2. Jakarta: Salemba Empat.

Dewet, Johanes. Eva Versus Traditional Accounting Measures Of Performance As Drivers of Shareholder Value - A Comparative Analysis. Journal Of Manajerial. University of Pretoria

Ghozali, I. 2009. Aplikasi Analisis Multivariate dengan Program SPSS. Badan Penerbit Universitas Diponogoro. Semarang.

Ghozali, Imam. 2005. Aplikasi Analisis Multivariate dengan Program SPSS. Badan Penerbit Universitas Diponogoro, Semarang.

Gujarati, Damodar N. 2003. Basis Econometrics. Third Edision. Mc Graw-Hill. International Edition.

Hakim, Nasution Arman. 2006. Manajemen Industri. Yogyakarta: CV. Andi.

Hakim, Rahman. 2006. Perbandingan Kinerja Keuangan Perusahaan dengan Metode EVA, ROA, dan Pengaruhnya terhadap Return Saham pada Perusahaan yang tergabung dalam Indeks $L Q 45$ di Bursa efek Jakarta. Universitas Islam Indonesia. Yokyakarta.

Hansen, Don R. Maryanne, M. Mowen 2000. Akuntansi Manajemen. Edisi Kedua. Terjemaham: A. Hermawan. Jakarta: Erlangga.

Hartono, Jogiyanto 2001. Teori Portofolio dan Analisis Investasi. Edisi Keempat. Yogyakarta: BPFE-UGM.

Hartono, Jogiyanto 2003. Teori Portofolio dan Analisis Investasi: Edisi Kelima. BPFE. Yokyakarta.

Hartono, Jogiyanto dan Chendrawati. ROA and EVA : A Comparative Empirical Study, Gajah Mada Internal. Journal of Business, Vol 1, No 1, May 1997.

Husnan, Suad. 2005. Dasar-Dasar Teori Portofolio dan analisi Investasi Sekuritas. Yokyakarta: UPP AMP YKPN. 
Husnan, Suad. 1996. Dasar- Dasar Teori Portofolio dan Analisa Sekuritas. Edisi ke dua, Yokyakarta: UPP-AMP YKPN.

Husnan, Suad. Pujiastuti, Enny. 2004. Dasar-Dasar Manajemen Keuangan Edisi Keempat. Yogyakarta: UPP AMP YKPN.

Jama'an. 2008. Pengaruh Mekanisme Corporate Governance Terhadap Integritas Informasi Laporan Keuangan. Semarang: Universitas Diponogoro.

Kabu, Muslim. Teori Sinyal. (2011). (online). (diakses 3 Januari 2013). Tersedia di www:http//ekonomi. Kabo.biz.com

Koesno. Analisis untuk Memiliki dan Membeli Saham. Info Pasar Modal. 1990: 31-36.

Kusumawati, Rita dan Susilowati, Fitri, 2004, Analisis Pengaruh Faktor Fundamental terhadap Return Saham. Jurnal Analisis Bisnis dan Akuntansi, UM Magelang. Vol 2 no 1 April:69.

Lambas, Raja J. Pangabean. Analisis Perbandingan Korelasi EVA dan ROE Terhadap Harga Saham LQ 45 di Bursa Efek Jakarta. Jurnal Manajemen \& Bisnis Sriwijaya Vol. 3 No. 5 Juni 2005.

Lehn, K. \& Makhija, A.K. 1996. EVA and MVA as performance measures and signals for strategic change. Strategy \& Leadership, May/June:34-38.

Lisa, Linawati. 1999. Economic Value Added Sebagai Ukuran Keberhasilan Kinerja Manajemen Perusahaan. Jurnal Akuntansi dan Keuangan Vol. 1, No 1, Mei 1999, Hal 28-42, Jurusan Ekonomi Akuntansi, Fakultas Ekonomi. Universitas Kristen Petra.

Mirza, Teuku dan S, Imbuh, Konsep Economic Value Added: Pendekatan, untuk menenukan Nilai Rill perusahaan dan Kinerja Riil Manajemen, Usahawan No 01 Th XXVIII, Januari 1999.

Pradhono dan Jogi Chritiawan, Yulius. 2004. Pengaruh Economic Value Added, Residual Income, Earnings dan Arus Kas Operasi Terhadap Return yang Diterima oleh Pemegang Saham. Jurnal Analisis Bisnis dan Akuntansi, UM Magelang. Vol 2 no 1 April:69.

Nugroho, Agung. 2005. Strategi Jitu Memilih Metode Statistik Penelitian dengan SPSS. Penerbit Andi, Yokyakarta.

Praswoto, Dwi. 1995. Analisis Laporan Keuangan: Konsep dan Aplikasi, Yokyakarta: UPP AMP YKPN.

Patel, Ritesh. 2012. Impact of Economic value added (EVA) on Share price:A study of Indian Private Sector bank. International Journal of Contemporary Business Studies. Vol: 3, No: 1. January.

Purnomo, Yogo. Keterkaitan Kinerja Keuangan dengan Harga Saham. Usahawan No.12 Th XXVII, Desember 1998: 33-38

Riyanto, Bambang. 2001. Dasar-Dasar Pembelanjaan Perusahaan: Cetakan 7, BEP. Yokyakarta

Rousana, Mike. Memanfaatkan EVA untuk Menilai Perusahaan di Pasar Modal Indonesia. Usahawan No, 04 Th XXVI. April 1997: 18-21. 
Saham: Pengertian, definisi, jenis, nilai, harga dan belajar saham. (2002). (online). (diakses 2 Januari 2013). Tersedia di www: http//sarjanaku.com

Santoso, Singgih. 2005. Menguasai Statistik di Era Informasi Dengan SPSS 12. PT Alex Media Komputindo: Jakarta.

Sasongko, Noer dan Nila Wulandari. 2006. Pengaruh EVA dan Rasio-Rasio Profitabilitas terhadap Harga Saham Perusahaan Manufaktur di BEJ. Empirika, Vol. 19 No. 1, Juni, hal 64-80.

Sawir, Agnes. 2003. Analisis Kinerja Keuangan dan Perencanaan Keuangan Perusahaan. Jakarta: Gramedia Pustaka Utama.

Sekaran, Uma. 2007. Research Methods For Business- Metodologi Penelitian untuk Bisnis. Edisi 4 buku 1 dan 2. Salemba Empat. Jakarta.

Sihasale, Hermina. 2001. Analisis Pengaruh Kinerja Keuangan Perusahaan Terhadap Harga Saham Perusahaan Manufaktur yang Terdaftar di Bursa Efek Jakarta. Tesis. Program Studi Magister Akuntansi Fakultas Ekonomi, Universitas Diponogoro. Semarang.

Stewart, Stern \& Co., Economic Value added. Retrieved April 4, 2007. From http:// www.sternstewart.com/evaabout/whatis.php.

Stewart, Using EVA for Performance Measurement and Financial Management in the New Economy: Interment, www.stewart eva.com.

Sugiyono. 1999. Statistika untuk Penelitian. Bandung: CV Alfabeta.

Sugiyono. 2004. Metode Penelitian Bisnis. Bandung: Penerbit CV. Alpha Beta.

Utama, Sidharta. Economic Value Added: Pengukur Penciptan Nilai Perusahaan. Usahawan No. 04 Th XXVI, April 1997: 10-15

Uyemura, D.G., Kantor, C.C. \& Pettit, J.M. 1996. EVA for banks: value creation, risk management, and profitability measurement. Journal of Applied Corporate Finance, Vol. 9, no 2, Summer:94-109.

Warsono. 2001. Analisis Investasi dan Manajemen Portofolio, Edisi Pertama. Penerbit UM Press, Malang.

LAMPIRAN

Tabel 1. Hasil Deskriptif Statistik

\begin{tabular}{|l|c|r|r|r|r|}
\hline & $\mathrm{N}$ & \multicolumn{1}{|c|}{ Minimum } & Maximum & Mean & Std. Deviation \\
\hline ROA & 192 & $-2,66$ & 4,53 & 2,002 & 1,13223 \\
ROE & 192 & $-1,47$ & 4,73 & 2,465 & 1,02609 \\
EPS & 192 & 0,03 & 4,74 & 2,576 & 0,88132 \\
EVA & 192 & $-1,56$ & 4,63 & 1,907 & 1,20827 \\
Return saham & 192 & 0,31 & 4,54 & 2,259 & 0,83845 \\
Valid N & & & & & \\
(listwise) & 192 & & & & \\
\hline
\end{tabular}

Sumber: Data Sekunder, diolah 2013 
Tabel 2. Hasil Pengujian Normalitas Data

\begin{tabular}{|c|c|c|c|c|}
\hline Variabel & $\begin{array}{c}\text { Kolmogrov } \\
\text { Smirnov Test }\end{array}$ & $\begin{array}{c}\text { Asymp. Sig } \\
\text { (2-Tailed) }\end{array}$ & $\rho$-value & Kesimpulan \\
\hline ROA & 1,224 & 0,100 & $\mathrm{p}>0,05$ & Distribusi Normal \\
ROE & 1,554 & 0,140 & $\mathrm{p}>0,05$ & Distribusi Normal \\
EPS & 0,782 & 0,574 & $\mathrm{p}>0,05$ & Distribusi Normal \\
EVA & 1,068 & 0,204 & $\mathrm{p}>0,05$ & Distribusi Normal \\
Return Saham & 0.509 & 0,958 & $\mathrm{p}>0,05$ & Distribusi Normal \\
\hline
\end{tabular}

Sumber: Data sekunder, diolah 2013.

Tabel 3. Hasil Uji Autokorelas

\begin{tabular}{|l|r|r|r|r|r|}
\hline Model & $\mathrm{R}$ & $\mathrm{R}$ Square & $\begin{array}{c}\text { Adjusted R } \\
\text { Square }\end{array}$ & $\begin{array}{c}\text { Std. Error of the } \\
\text { Estimate }\end{array}$ & $\begin{array}{c}\text { Durbin- } \\
\text { Watson }\end{array}$ \\
\hline 1 & $0,997 \mathrm{a}$ & 0,994 & 0,994 & 0,06618 & 1,738 \\
\hline
\end{tabular}

Sumber: Data sekunder diolah, 2013

Tabel 4. Hasil Multikolinearitas

\begin{tabular}{|c|r|r|r|r|}
\hline & \multicolumn{2}{|c|}{ Model } & \multicolumn{2}{|c|}{ Model } \\
\cline { 2 - 5 } & Tolerance & VIF & \multicolumn{1}{c|}{ Tolerance } & \multicolumn{1}{|c|}{ VIF } \\
\hline (Constant) & & & & 4,617 \\
ROA & 0,195 & 5,124 & 0,217 & - \\
ROE & 0,014 & 72,401 & - & 6,419 \\
EPS & 0,015 & 67,895 & 0,156 & 3,156 \\
EVA & 0,317 & 3,157 & 0,317 & \\
\hline
\end{tabular}

a Dependent Variabel: Return Saham

Sumber: Data sekunder diolah, 2013

Tabel 5. Hasil Uji Heterokedastisitas Sebelum Diperbaiki

\begin{tabular}{|l|r|r|r|r|r|}
\hline & \multicolumn{2}{|c|}{ Unstandardized Coefficients } & $\begin{array}{c}\text { Standardized } \\
\text { Coefficients }\end{array}$ & & \\
\cline { 2 - 4 } Model & $\mathrm{B}$ & Std. Error & Beta & $\mathrm{t}$ & \multicolumn{1}{c|}{ Sig. } \\
\hline \multirow{2}{*}{ 1 (Constant) } & 0,198 & 0,037 & & 5,330 & 0,000 \\
ROA & $-0,056$ & 0,019 & $-0,440$ & $-3,008$ & 0,003 \\
EPS & 0,012 & 0,028 & 0,071 & 0,410 & 0,682 \\
EVA & 0,003 & 0,014 & 0,027 & 0,219 & 0,827 \\
\hline
\end{tabular}

a. Dependent Variable: ABSRES_3

Sumber: Data sekunder diolah, 2013 